\title{
World Global Systemic Crisis and the Local Self-Government Basic Ideals
}

\author{
Solovev Sergey Gennadevich ${ }^{1}$, Sirekanyan Vachagan Vaghinakovich ${ }^{1} \&$ Abushenko Dmitry Borisovich $^{1}$ \\ ${ }^{1}$ South-Ural State University (National Research University), Miass, Chelyabinsk region, Russian Federation \\ Correspondence: Sirekanyan Vachagan Vaghinakovich, South Ural State University (SUSU) (National Research \\ University), 456304, 10A, 8 Iulya str., Miass, Chelyabinsk region, Russian Federation. Tel: 8-351-352-1160; \\ 8-351-353-2882. E-mail: vachagan@sirekanyan.com
}

Received: March 9, 2015 Accepted: March 26, 2015 Online Published: June 5, 2015

doi:10.5539/ass.v11n18p267 URL: http://dx.doi.org/10.5539/ass.v11n18p267

\begin{abstract}
The purpose of this paper is to consider the main normative documents conceptual development fixing the modern Russian and European systems of local self-government ideals in the world global system crisis conditions affecting conceptual and ideological bases of all spheres in modern world order. The theoretical and practical aspects are analyzed by the author on given problem.
\end{abstract}

Keywords: Local self-government ideals, Russian Federation (RF) Constitution, European Charter of Local Self-Government (EChILS-G)

\section{Introduction}

No matter where we are in. It is important what we are moving to!

Conceptual aphorism

The world global system crisis which is currently experiencing in many countries in the world has not only the economic content (Glazyev, 2010). Obviously it affects the conceptual and ideological foundations of the modern world order defining the system of local self-government ideals. Certain confirmation of this is the fact of clearly marked representative locally democracy crisis in many countries, including even developed countries in today's world. The crisis tendencies are manifested quite clearly:

1. in the fall of local elections voters turnout in the Czech Republic, Germany, France (Goldsmith \& Page, 2010a; 2010b);

2. in the low voter turnout in the United Kingdom and the United States (Vogel, 2007);

3. in reducing the number of persons wishing to take local elective positions in Australia and the UK (Morphet, 2008);

4. in the complicated procedure of acting mayor displacement by the voters in Poland (Cherkasov, 2014).

According to the Russian Federation President's information in Russian local self-government system also has been accumulated a lot of problems related to the local self-government implementation in general and particularly implementation of representative democracy at local level (The Russian Federation President's Message to the Federal Assembly, 2013). At the same time, many researchers of local self-government processes note that this situation cannot but cause concern about the local government system democratic legitimacy (Morphet, 2008). It should be noted that marked crisis did not arise today, they have sufficiently long history. In different countries various attempts had been made and are taken now to revive the population activity at the local level, to make the municipal system more attractive for the population, to expand the forms of direct citizen participation in local decision-making (John, 2006). However, despite all efforts, the crisis in the local self-government organization is growing. In this connection it can be concluded, with a high probability, that the existing system of knowledge about the local self-government system organization requires improvement. A rethinking of ideals (landmarks) specific to the modern local self-government system achievements are required, as well as a system of methods and means to achieve the designated ideal forms. 
In connection with above question on ideals system in Russian current local self-government presents a great importance for the Russian municipal law theorists and also Russian municipal construction practitioners (Vasiliev, 2014; Timofeev, 2014). It is caused by the fact that many life's ideals in normative legal acts are fixed in our society, and are realized through them. Thus, the Russian local self-government ideal forms define the vector of its further development getting fixation in the relevant legislation system.

At the same time the local self-government true ideals (ideal forms of local self-government implement defining the correct and implemented benchmarks motion) should be distinguished from:

1) the local self-government false ideals (ideal self-government forms, giving incorrect, deadlock benchmarks of motion);

2) the self-government myths (ideal self-government forms, giving illusory, objective unattainable benchmarks motion).

In this case, it is clear that the only objective criterion for delimitation the true self- government ideals from the false one and the Russian local self-government myths can only serve a positive experience of practical implementation in ideal self-government various forms both in the Russian Federation and in foreign countries.

Analyzing the self-government ideals question in Russian society, it should be pointed to the fact that the notion of "ideal" is distinguished from the concept of "value". Terminologically, value suggests certain criteria in the price form i.e. value or significance more broadly or something else. Value carries with it price but the ideal cannot be bought or sold, it has no value, it represents ideal form (landmark) to which it is no matter to strive for. In this connection the municipal law theory should clearly delimit local self-government and self-management conceptual and terminological ideals.

It is important to understand that ideals are not fully achievable as they lead themselves to the lighthouse. In this connection a question arises about the correctness of the chosen course performance moving to the ideal self-management forms. How to evaluate this and whether it is true to go on? Obviously the only objective criterion of approximations to the selected self-managed form will be language of life circumstances characterizing the improvement of situation in municipalities.

Moreover it is extremely important from the municipal ideology viewpoint to isolate municipal law from the extensive array of ideal theoretical constructs, various ideal local government forms and to solve the question in case of their truth or falsity for municipal construction.

To connection with this it is particular importance analysis of basic ideas embodied in legal documents constituting the modern local self-government conceptual basis. It is important to sort, analyze these ideas and solve the further using problem.

It should take into account the fact that part of local self-government legal basis includes generally recognized principles and norms of international law fixing them in an international treaty precedence over the Russian Federation laws and its subjects, according to the Russian Federation current Constitution part 4 Article 15. The ideas can be contained in these mentioned documents which do not fit into ideals system formed in Russian society, as a whole, and in particular into the Russian local self-government ideals system.

Besides them, it is important to take into consideration the fact that every nation in the world is characterized by certain ideals and their resulting organization of local self-government traditions solving local matters which it carries through the centuries and sometimes through the millenniums. The peoples living in the Russian Federation territory also have their own local life experience which is unique in many ways. At the same time one should remember that management concepts which were born and working at an environment of one society may not always be used in another one (Solovev, 2014).

\section{European Charter Ideals of the Local Self-Government}

It must be clear the content of basic ideas (ideal forms) enshrined in this normative document and also to understand their main values as in April 11, 1998 the Russian Federation ratified the European Charter of local Self-Government (EChlS-G) adopted on October 15, 1985 and currently representing the basic international legal instrument in local self-government field. Clear understanding the content of EChIIS-G basic ideals acquires special significance at the present time due to a representative democracy crisis at the local level in many foreign countries 2. (Goldsmith \& Page, 2010a; 2010b; Vogel, 2007; Morphet, 2008; Cherkasov, 2014; Steytler, 2009) for a long time building its local self-government system according to the ideals enshrined in above indicated normative document. 
It should be remembered about an existence of authentic understanding the problem and describing contents of international legal concepts in task's context providing the Russian Federation single legal space (Solovev, 2014). In this regard it is fundamentally important the terms and expressions used in Russian edition of EChILS-G as accurately as possible to content of terminology used in Russian legislation acts regulating the relevant legal relationship (Zamotaev \& Chekalkin, 2007).

Analyzing the EChILS-G content it should be always clearly understood the fact that in European Charter of Local Self-Government preamble of the country- Council of Europe members identified as their goal to achieve greater unity between its members for the purpose of safeguarding and realizing the ideals and principles being their common heritage. Simply speaking the main purpose of this document is to standardize the implementation of local self-government in the European countries - signatories of this Charter.

In this case as the main ideals of local self-government organization to which the countries sought to conclude this Charter are fixed the following ideal constructions:

\subsection{Local Self-Governments' Competency Autonomy}

(In accordance with paragraph 2, 3, Article (Art.) 4 European Charter of Local Self-Government and local self-governments, within the limits established by law, have a full discretion for realization on any question by their own initiative which is not excluded from their competence sphere and is not administered by any other authority. As a rule the implementation of public authority should predominantly be on those authorities which are closest to the citizen. To transfer any function to some other authority must be carried out based on volume, nature of specific problems also the requirements of efficiency and savings).

\subsection{Local Self-Governments' Administrative Autonomy}

(According to the paragraph 1 of Art. 8 any administrative control per local government bodies in EChILS-G can be exercised only in the order and in cases provided by the Constitution or by law. Besides this, paragraph 1 of Art. 6 indicated Charter enshrines the position that local authorities should be able to determine their own internal administrative structures, without disturbing more general statutory provisions, which they intend to create so that those can respond local requirements and ensure an effective management).

\subsection{The Local Self-Governments' Financial Autonomy}

(In accordance with paragraph 1, 2, Art. 9 EChILS-G, local governments have the right to adequate their own financial resources, within the framework of national economic policy, which they may freely dispose in exercising their authority. The local self-governments financial resources should be commensurate with the responsibilities provided for by the constitution or by law).

\subsection{Local Self-Governments' Territorial Autonomy}

(In accordance with Art. 5 EChILS-G any changing the borders of local self-government territories is permitted only taking into account the consent of their population including through a referendum where this is permitted by law).

In view of the above selection it is clear that the analyzed document is based on the priority of the statehood ideals, combining (integration) the territories, unification of management processes at the local level to the independence state ideals. Specific confirmation of this thesis is also the European countries persistent movement towards to the integration of territories management centralization and unification at the European Union level.

Furthermore analyzing these EChILS-G ideals it should be emphasized by the fact that all the ideal design define the motion vector to the autonomy of local governments specifying the motion vector to the local self-government autonomy but not to their autonomy orienting terminology by the absence of any restrictions.

At the same time systematic analysis of EChILS-G provisions allow to conclude that there are correct orientations in given document however it is not clearly defined the meaning of many terms used. For example, in European Charter of Local Self-Government text is not clear the meaning of terms such as "principles of democracy", "principles decentralization of power", "free exercise of the mandate," "local self-governments administrative supervision", "local self-governments financial resources" ...

Furthermore, in Art. 12 of this document is fixed the norm that the State which ratifies this document should be bound minimum 20 paragraphs out of 30. In this case, 10 paragraphs of the basic 14 are required listed in Art. 12. Another 10 paragraphs of countries ratifying this Charter should be selected from of the remaining 16 paragraphs. As a result the action of proposed scheme there can be a paradoxical situation as it is indicated by Y. Kirillov (Kirillov, 2010) when the country sign this Charter may not consider itself related paragraph 1, Art. 3 the 
European Charter of Local Self-Government fixing local self-government legal definition and understand that local self-government fundamentally is different phenomenon.

Clearly that such an approach to the normative document structure is quite disputable and it creates problems to EChILS-G as a tool for the European systems of local self-government development.

In this connection, it is appropriate to recall R. Dekart's appeal: "Clarify the meaning of the words and you will save humanity from half misconceptions" (Decart, 2011). At the present time it is quite simple to distort the words meaning and suitable images by 180 degrees to deploy the content of any idea and manipulate them (to interpret the content of such uncertain regulations by interpreter's wish). In our opinion something like that took place with the basic ideas content embodied in EChILS-G and defining the basis for the Russian local self-government organization.

The marked position is a consequence of the fact by 90 s of 20th century when in Russian public consciousness began to dominate an utopian notions of priority mechanisms being uncontrollable at local level self-organization. By analogy to religious faith-based doctrines, these ideas can be characterized as self-governing fundamentalism based on the dogma of self-government invisible hand as a universal, social control mechanism of local processes optimization.

During present time many municipal law and management experts come to the realization that the local government in municipality does not occur by itself. It should be organized. Schematically municipality is a control method when the regulator does not want to control the object himself directly but wants to do the right thing for regulator. In this case to control by self-government system is more effectively than through direct directive management control. However self-government is possible only in strictly defined extents which determine a higher- level management.

\section{The Local Self-Government's Ideals Established by the Russian Federation (RF) Constitution}

The Russian Federation (RF) constitution accepted by national voting on December, 121993 determines the ideal forms of local self-government organization which achievement is oriented the Russian people as well as the Russian State. Proceeding from analysis of the current RF Constitution text as self-governing ideals should be allocated as follows.

\subsection{Local Self-Government Competency Autonomy (Independence)}

This ideal form of local self-government organization involves the following components according to the authors of RF Constitution:

1) Local self-government within its powers is independent (Art. 12 of the RF Constitution).

2) The Russian Federation local self-government provides the local issues decision independently by population, as well as possession, use and disposal of municipal property (Part 1, Art. 130 of the Russian Federation Constitution).

3) Local self-governments manage municipal property independently, form, approve and implement the local budget, establish local taxes and fees, carry out public order protection and also solve any other local significance issues (Part 1, Art. 132 of the Russian Federation Constitution).

\subsection{Local Self-Government Financial Autonomy (Independence)}

The ideal structure orienting for the development of Russian local self-government system to achieve the financial independence fixed in part 1, Art. 132 of the RF Constitution contain the norm that local governments manage the municipal property independently, form, approve and implement the local budget, establish local taxes and fees.

\subsection{Local Self-Governments' Organizational Independence}

The following common structures are directed to achieve the local self-governments administrative autonomy, fixed norms of the Russian Federation Constitution:

1) Russian people exercise their power directly and through the organs of state power and local self-government (part 2, Art. 3 of the RF Constitution).

2) The local self-governments are not included in the system of state authorities (Art. 12 of the Russian Federation Constitution).

3) The local governments' structure is determined independently by the population (part 1, Art. 131 of the Russian Federation Constitution). 


\subsection{The Territorial Autonomy}

Orientation to the ideals of Russian territorial autonomy on local self-government is traced in the content of Art. 131 of the RF Constitution enshrining the norms in which shows that the local self-government is carried out in urban, rural settlements and in other territories in view of historical and other local traditions. Changing the borders of territories in which carried out local self-government is allowed to consider the population's opinion of respective territories.

\subsection{Local Self-Government Legal Protection}

The ideals of local government's legal protection are reflected in the Art. 133 of the RF Constitution, enshrined the regulations to the effect that local self-government in the Russian Federation shall be guaranteed the right to judicial protection, on compensation of additional expenses arising as a result decisions taken by the public authorities, ban on the limitations local self-government rights established by the Russian Federation Constitution and federal laws.

Thus, on the above basis ideal form of local self-government organization analysis in which the provisions of Russian Federation Constitution achievement is oriented can be concluded that in this legal act about the achievements of competency, financial, and local self-government organizational independence is said. Also they can be essentially inside landmark contraposition to the state authorities system in the single control mechanism structure by Russian state.

In this case the ideal forms comparative analysis suggests their conceptual similarity on which the achievement of EChILS-G and the Russian Federation Constitution are oriented. Both the EChILS-G and the Russian Federation Constitution as a benchmark for the development of local self-regulatory organization describe the appropriate system ideal form implying the definite separation of the state and municipal governance systems (local self-government). However, if the EChILS-G is oriented, as it is shown above, to achieve the autonomy of local self-government, then many norms of the Russian Federation Constitution aim at achieving the local government independence. This terminologically lays the motion vector to achieve absolute independence from the public authorities in matters of local importance.

In conditions of the huge range objective existence dependency local self-government system from the system of state even in matters of local importance is a movement to nowhere. It is a movement towards the achievement of local self-government independence. But nowadays the same local self-government system needs a true and not a deadlock vector in the Russian Federation. In this regard usage of the term "autonomy" to denote a certain degree of local government independence system from the system of government in this sense is preferable than using the term "independence".

Thus it is necessary always keep in mind that both the autonomy and independence in relation to local self-government are methods of movement to a particular purpose but not the goal itself. It is obvious that the main purpose of self-government systems implementation in the governance mechanism is to achieve an optimal scheme for the local issues solving. Here it is important to remember the "local issues" notion is not sufficiently specific because the state is responsible for the decision to limit all internal issues irrespective of their delegating by the various derivatives in public or exceptionally public organizations.

With this similar approach the state as a subject should be considered a local self-government system creator transmits it for the implementation of the public power functions and establish a mechanism mediated control over the functioning system operating in the self-government mode.

One can argue about the appropriate forms and methods of the system control in local self-government but they are secondary points in our sense. The main thing in given management scheme is that the state can solve its problems directly through the government bodies or indirectly through the local self-governments. In this case of course the local self-government system transmission to a public power state is obliged to ensure control over the created system of movement trajectory and take certain corrective actions in case of necessity.

Certainly it should be accept by the fact that the local government independence idea within its power is sufficiently tempting. However the illusion is a beautiful phenomenon but also it is deceptive and sometimes its price is very high. Long-term absolute independence even within their own powers of municipalities can not be achieved as a part (municipality) can not function independently from the whole in limit of liability for the operation of all component parts (states).

Given thesis confirms the fact that autonomy in local self-government is not the purpose but a means. If the self-government process within a particular municipality takes place in acceptable limits (local self-government system is functioning properly and local issues are resolved timely manner and fully) then the state does not 
make sense to intervene in this local self-government process. If the so-called local issues can not be solved in the municipality the State is obliged to take the whole organizational and legal complex measures to solve local issues in the given territory as a subject which was created to address of totality public affairs in subordinated territory.

The above line of thinking confirms the Russian local self-government regulatory framework practice development. Thus, in accordance with Article 75 Federal Law Act from 06.10.2003 \# 131-FL "About the general principles of local self-government organization in the Russian Federation" legislatively stipulated the procedure for temporary implementation by public authorities of local self-governments certain powers. In Article 74 Federal Law Act establishes the procedure for impeachment the Municipal head or heads of local administrations by the Russian Federation highest official which is the government representative system. In paragraph 6.1 Article 36 of Federal Law Act established the grounds preschedule termination the Head of the municipality powers in connection with loss a confidence to the Russian Federation president.

Furthermore, in accordance with the latest amendments to Federal Law of 06.10.2003 \# 131-FL "About the general principles of local self-government organization in the Russian Federation" the Russian Federation Subjects based on paragraphs 1.2 p. 9 Art. 17 received their own laws right to carry out redistribution of powers between local self-governments and the Russian Federation government authorities in local issues sphere.

These examples show that in the Russian Federation purposefully introduced legal institutions which establish operational state control mechanisms over the local self-government implementation in which there is a gradual abandonment of the ideals defining motion vector to achieve independence in local self-government system implying hard separation and opposition to government system.

\section{The Prospects}

At the present time motion to the ideals is clearly felt in Russian Federation legal system presupposing incorporation the local self-government system into a public authority single mechanism suggesting the presence of real legal mechanisms. This provides as responsibility of public authorities for the implementation of all publicly-power issues in the Russian state territory so the effective mechanisms to ensure the implementation of its tasks. In our view, Russian legislator's movement does not only contradict the ideals of local self-government autonomy enshrined in the European Charter of Local Self-Government but it is a good example to realize their actual content responding the criteria of reasonableness.

In this case, it should be remembered that the process of cognition both objective reality and municipal legal are continual. The exact answer to the question about the actuality of local government autonomy ideals, certainly, the time will give us. However considering the fact that any process is manageable and one of the criteria for the certain ideals truth is repeatability of results, we can conclude that studying Russian statehood history nowadays clearly shows lack of prospects of idealization in various forms of territorial or competency crushing against public state power systems and ineffectiveness attempt of formation inside the public education which is absolutely competency independent in various spheres of social life.

\section{References}

Cherkasov, A. I. (2014). The crisis of representative democracy at local level in foreign countries and its overcome mechanisms. Municipal Service: legal issues, 1.

Decart, R. (2011). Discourse on Method to guide correctly your mind and find the truth in sciences and in other philosophical works. Moscow: Academic Project.

Glazyev, S. Yu. (2010). The strategy of outstripping development in Russia during the global crisis. Economics.

Goldsmith, M. J., \& Page, E. C. (Eds.). (2010a). Changing government relations in Europe: from localism to intergovernmentalism (p. 32). London.

Goldsmith, M. J., \& Page, E. C. (Eds.). (2010b). Changing government relations in Europe: from localism to intergovernmentalism (p. 94). London.

John, P. (2006). Local governance in Western Europe (p. 16). London.

Kirillov, Y. V. (2010). European Charter of Local Self-Government. Municipal Law, 3, 13.

Morphet, J. (2008). Modern local government (p. 15). London.

Solovev, S. G. (2014). Local government and state power: the constitutional separation of the unification (based on the Russian Federation President's message). Municipal Law, 2, 2-6.

Solovev, S. G. (2014). Municipal Code of the Russian Federation as a tool for solving a number of legal 
problems of local self-government. World Applied Sciences Journal (WASJ), 30, 995-999.

Steytler, N. (Ed.). (2009). Local government and metropolitan regions in federal systems (p. 126). Montreal.

The Russian Federation President's Message to the Federal Assembly. (December 12, 2013). Retrieved February 28, 2014, from http://www.kremlin.ru/transcripts/19825

Timofeev, N. S. (2014). Local government as the New Year's Eve expectation (the 150th anniversary of the Zemstvo (district council). Constitutional and Municipal Law, 5, 52-58.

Vasiliev, V. I. (2014). Don’t forget the Main. Local Rules, 2, 3-8.

Vogel, R. K. (2007). Multilevel governance in the United States. In H. Lazar, \& Ch. Leuprecht (Eds.), Spheres of government: comparative studies of cities in multilevel governance systems (p. 278).

Zamotaev, A. A., \& Chekalkin, V. I. (2007). About the Russian edition to European Charter of Local Self-Government: some issues to ensure the adequacy of Europe Council application documents relating to the public authority exercise. Municipal authorities, 1, 6-20.

\section{Copyrights}

Copyright for this article is retained by the author(s), with first publication rights granted to the journal.

This is an open-access article distributed under the terms and conditions of the Creative Commons Attribution license (http://creativecommons.org/licenses/by/3.0/). 